Review

\title{
Diversity Patterns of Benthic Macrofauna Caused by Marine Fish Farming
}

\section{Carlos Sanz-Lázaro * and Arnaldo Marín}

Departamento de Ecología e Hidrología, Facultad de Biología, Universidad de Murcia, 30100 Murcia, Spain; Tel.: +34 968364977; Fax: +34 968363963; E-Mail: arnaldo@um.es

* Author to whom correspondence should be addressed; E-Mail: carsanz@um.es; Tel.: +34-868884977; Fax: +34-868883963.

Received: 8 October 2010; in revised form: 25 March 2011 / Accepted: 25 March 2011 / Published: 14 April 2011

\begin{abstract}
This paper reviews the patterns observed in the diversity and structure of the macrofauna benthic community under the influence of fish farming. First, we explain the effects of organic enrichment on the sediment and the consequences for the inhabiting communities. We describe the diversity trends in spatial and temporal gradients affected by fish farming and compare them with those described by the Pearson and Rosenberg model. We found that in general terms, the trends of diversity and other community parameters followed the Pearson and Rosenberg model but they can vary to some extent due to sediment local characteristics or to secondary disturbances. We also show the different mechanisms by which wild fish can affect macrofauna diversity patterns under fish farming influence. In addition, we comment the importance of the macrofauna diversity in the ecosystem functions and propose some guidelines to measure functional diversity related to relevant processes at ecosystem level. We propose more research efforts in the main topics commented in this review to improve management strategies to guarantee a good status of the diversity and ecosystem functioning of sediments influenced by fish farming.
\end{abstract}

Keywords: aquaculture; organic enrichment; benthic diversity; Shannon-Wienner; abundance; species richness; biomass; Pearson-Rosenberg model; macrofauna; community structure; spatial and temporal patterns; ecosystem functioning; functional diversity; sediment metabolic capacity 
Abbreviations: OM, organic matter; H', Shannon-Wiener diversity; Pearson and Rosenberg model, P-R model

\section{Introduction}

Marine fish farming has experienced an almost exponential growth over recent decades and, worldwide, is the fastest growing food production system [1]. Very soon, fish consumed from fish farming is expected to match the fish consumed from fisheries. For a correct environmental management, it is important to have a good knowledge about the processes that regulate the effects of the aquaculture residues on the ecosystem.

The greatest source of wastes in aquaculture is the organic matter (OM) that comes from the feeding of cultured fish [2]. This OM is relatively rich in organic carbon and nutrients such as nitrogen and phosphorus [3] and is released in two forms, particulate and dissolved. Particulate wastes come from uneaten feed and fish feces, while dissolved wastes come from fish feces and excretions derived from fish metabolism, such as urea [4-6]. The impact fish farming has, is usually more obvious in the benthos than in the water column, where particulate wastes tends to accumulate in the proximity of fish farm leases $[5,7,8]$. Hence, the deposition rates of particulate OM below the fish cages can be considerably higher than the background levels [9-12].

The accumulation of $\mathrm{OM}$ on the surface of the sediment enhances sediment metabolism, and so does the sediment oxygen uptake, since oxygen is the electron acceptor which aerobic bacteria uses for respiration [13]. Oxygen concentration in the sediment porewater is limited and depends largely on the exchange rate with water from the sediment surface, which has higher oxygen content. In the porewater, if the oxygen supply is less than the consumption of oxygen, oxygen levels decrease resulting in hypoxia or even anoxia. This produces profound changes in the sediment metabolism. Since aerobic bacteria can no longer mineralize the OM, this, in turn, becomes mineralized by anaerobic bacteria [14]. Anaerobic bacteria have a less efficient metabolism and use other electron acceptors for respiration, and therefore, OM tends to accumulate in the seabed at even higher rates.

Of the different types of anaerobic metabolic pathways, sulfate reduction is the most important in conditions of organic enrichment $[15,16]$. Sulfate reduction uses sulphate as the electron acceptor and produces sulfides as a by-product. Sulfides can be dissolved in the pore water and have detrimental consequences for the organisms inhabiting the sediment. Sulfate is a compound abundant in sea water and so it is very unlikely to be depleted. However, if the metabolic rate is very high, the sulfate can be exhausted leading to methanogenesis. This anaerobic metabolic pathway produces a by-product, which is also toxic, methane (for a more detailed description see $[17,18]$ ).

Although OM is considered the most important source of pollution derived from fish farming, other pollutants may also have adverse effects on the benthic communities, such as metals, mainly $\mathrm{Cu}$, $\mathrm{Zn}$ and Cd [19,20], as well, as chemotherapeutic substances [21]. These contaminants may have interactive effects [22], and can also produce changes in diversity and structure of benthic communities.

Among the benthic communities, the macrofauna is the community that includes the animals that are retained in a sieve of $0.5 \mathrm{~mm}$. The main taxa that comprise the macrofauna are the phyla: Arthropoda (mainly crustaceans of the malacostraca group), Mollusca (mainly bivalves and gastropods) and Annelida (mainly polychaetes). Macrofauna has been widely used to assess different 
types of pollution [23], including impacts on the benthos associated with aquaculture [8,24,25]. This is because macrofauna has several features that make it reliable for this task: (a) usually show a considerably high diversity at species level [26]; (b) despite macrofauna species have life cycles with variable time spans, these are relatively short, compared to other communities such as seagrasses or vertebrates, which in turn, gives the community a rapid response capacity to new conditions; (c) different macrofauna species have different levels of tolerance and different biology (regarding to feeding habits, habitat type, etc.); and (d) despite larval dispersion, they have a reduced mobility compared with other groups of species such as fish, and so, they tend to remain on the site after the impact has occurred [27].

Besides the role of the macrofauna as a sentinel community of antropogenic impacts, macrofauna plays a major role in ecosystem functions such as OM mineralization and nutrient recycling [28]. These tasks are carried out primarily by the bacteria inhabiting the seabed, but macrofauna enhances them through active biological transport, i.e. bioturbation (active mixing of sediment) and bioirrigation (active flushing of solutes). These processes produce an increase in the supply of oxygen and other electron acceptors of the seabed surface with the porewater. This increases the metabolic capacity of bacteria and, in turn, of the sediment, to mineralize OM [29,30] and recycle nutrients [31] (Figure 1).

Figure 1. Effect of active biological transport on the sediment promoting oxic and suboxic metabolism, as well as sulfate reduction. Modified from Meysman et al. [32].

Sediment without fauna

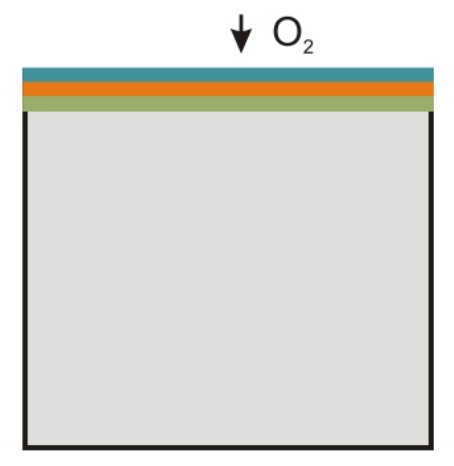

Diffusive transport of $\mathrm{O}_{2}$
Sediment with fauna

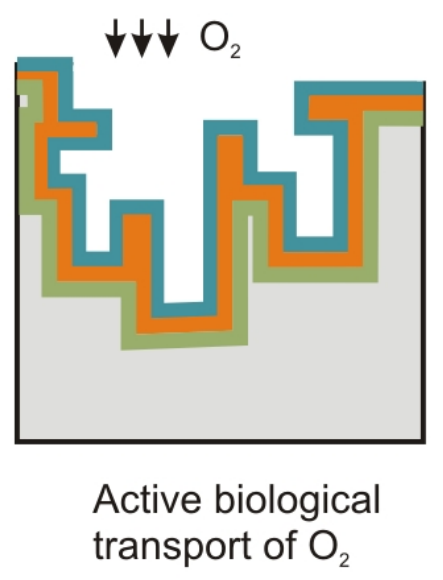

Oxic metabolism

Suboxic metabolism

Sulfate reduction

Methanogenesis 
The macrofauna also mineralizes OM directly, through consumption of OM. This process may account for up to $15 \%$ of the total sediment respiration [33]. Following this reasoning, the macrofauna population can grow as the availability of $\mathrm{OM}$ increases to a certain threshold. A larger population of macrofauna will consume more OM and limit the likelihood that OM accumulates in the sediment.

As for the recycling of nutrients, OM degradation in the sediment releases inorganic nutrients to the water column [34], which become available to primary producers [35]. Through denitrification (the microbial reduction of nitrate to dinitrogen gas) nitrogen can be removed from the system permanently. Thus, denitrification is of major importance for the nitrogen cycle and nutrient balance in coastal systems, being one of the few processes capable of counteracting eutrophication [36,37]. Denitrification shows the highest rates where there is an oxic/anoxic interface within the sediment, an environment which is enhanced by macrofauna through active biological transport [38,39]. Active biological transport decreased activity, associated with reduced conditions of sediments due to organic enrichment, disrupts denitrification [40], which can unbalance the nutrient cycle and promote eutrophication [41].

The macrofauna also plays a key role in the sulfur cycle. In the porewater, macrofauna favors the oxidation of toxic by-products of anaerobic metabolism, mainly dissolved sulfides, hampering their toxicity [33]. While in the sediment, Fe-S compounds derived from sulfide reduction and then bound to iron are also oxidized. This process helps to release Fe, recharging the sulfide buffering capacity of the sediment [42].

Traditionally, the macrofauna has been characterized from a univariate perspective, using metrics such as abundance, biomass and diversity. As for diversity, the most intuitive and simple measure is the species richness. Other measures of diversity take into account not only the number of species but also the structure/evenness within the species. Some of the most commonly used indices include Shannon-Wiener ( $\left.H^{\prime}\right)$, Margalef, Pielou, Simpson, Hurlbert's E (Sn), etc. These measurements are widely used in describing the community structure as well as the environmental assessment [43].

The spatial and temporal patterns of macrofauna diversity under conditions of organic enrichment has been widely documented in the Pearson and Rosenberg model ([44]; P-R model), a seminal and still highly relevant definition of spatial organic enrichment gradient. This successional model describes a reversible continuum of faunal change from an un-perturbed species rich community to a perturbed species poor one [45]. The P-R model defines four stages of benthic succession: normal, transitory, polluted and grossly polluted, dependent on the level of organic enrichment in the sediment. The P-R model describes a gradient where the species diversity decreases with increasing inputs of $\mathrm{OM}$, reaching a point where the fauna is completely depleted (the grossly polluted stage). Along this gradient, there is a simplification of the trophic structure (which become dominated by deposit feeders) and the active biological transport activity (Figure 2A).

In addition, the P-R model states a theoretical trend of abundance, biomass, species richness and $H^{\prime}$ along the gradient of organic enrichment, which has been widely reproduced and modified in many later works. For all these descriptors of the community, there is a common trend of an initial increase as OM load increases, with a peak at intermediate stages of organic enrichment, followed by a decrease until sediments become azoic. The phase in which each community descriptor peaks varies. $H$ ' shows the highest value at the ecotone point, which is defined by a community of low abundance, low species richness and low biomass. After the ecotone, the polluted zone occurs, where the peak of 
abundance (of opportunistic species) is found. Between the ecotone and the normal stage there is the transitory stage (Figure 2A).

Figure 2. In both graphs, the upper boxes refer to the stages defined in the P-R model [44]. (A) Abundance (A), biomass (B), species richness (S) and Shannon-Wiener diversity ( $H^{\prime}$ ) trends along an organic enrichment gradient according to the P-R model adapted from Pearson and Rosenberg [44] and Hyland et al. [46]. PO, peak of opportunists; E, ecotone point. At the bottom of the graph the two arrows show the tendency of oxygen and toxicant concentration in the sediment along an organic enrichment gradient. Toxicant refers to substances derived from the OM load which may cause pollution, such as: by-products derived from anaerobic metabolism $\left(\mathrm{NH}_{3}, \mathrm{H}_{2} \mathrm{~S}\right.$, and $\left.\mathrm{CH}_{4}\right)$, inorganic nutrients and pollutants. (B) General diversity (measured as $H^{\prime}$ and Hurlbert's diversity) trend observed along organic enrichment gradients from several areas in the world [46,47].
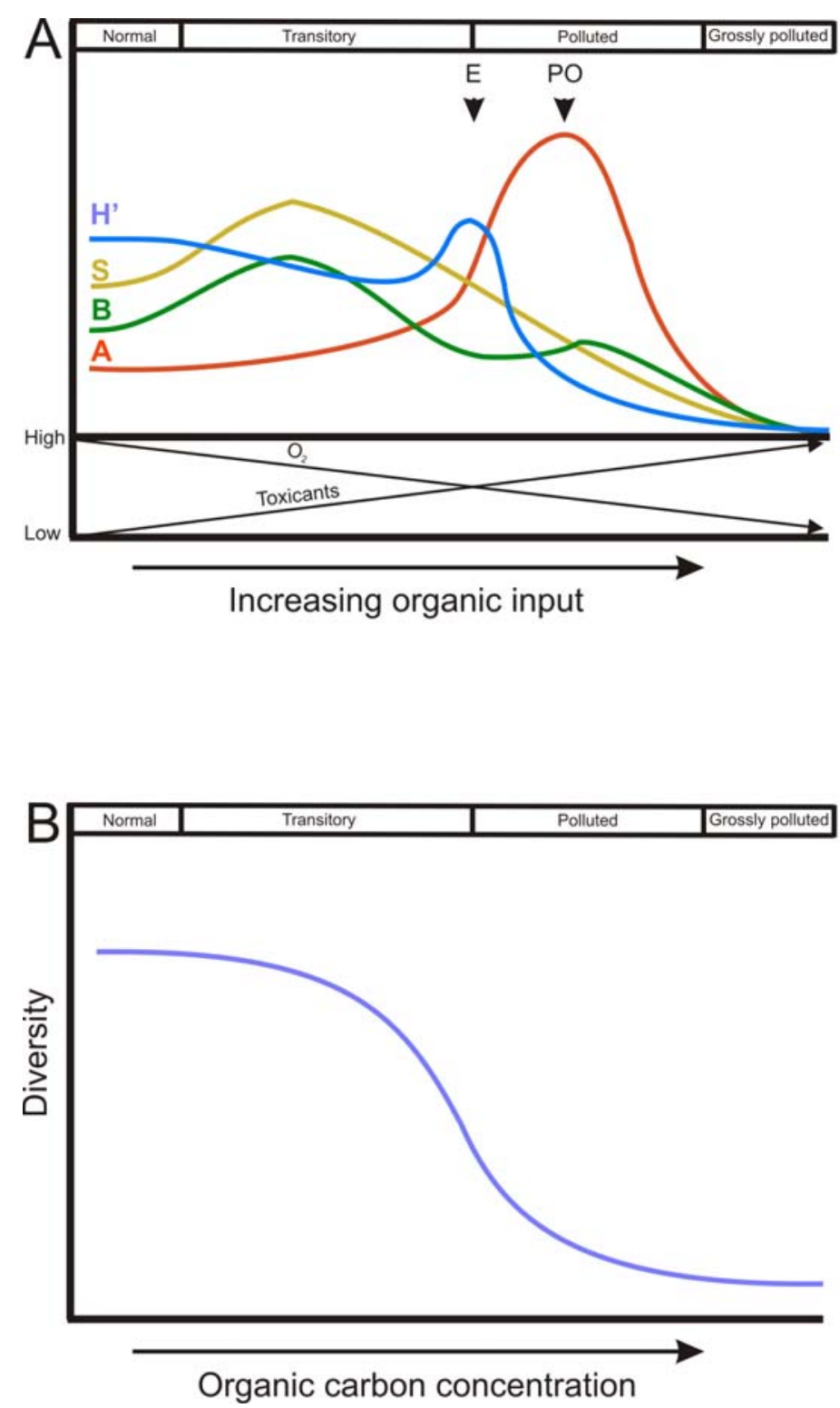

Advances in computer science have allowed scientists to study macrofauna diversity patterns using a multivariate approach. Multivariate techniques are robust tools that integrate all the species of the 
community by using matrices of macrofauna. These techniques can take into account, not just the number of species and individuals, but also the species identities and function. Hence, these tools can help in the study of the diversity of the macrofauna community, integrating its structure and composition. Additionally, multivariate techniques such as non-parametric multi-dimensional scaling (nMDS) are useful for studying macrofauna succession over spatial or temporal gradients. By using the distances within samples, we can get a representation of the stage and trend of the succession of a given community over a specific area or time span [24,48-51]. Nowadays, there are emerging techniques for measuring functional diversity that may help us to predict the loss of ecosystem functions caused by the loss of diversity [52].

In this paper we aim to review the diversity patterns of macrofauna under the influence of marine fish farming. First, we explain the spatial and temporal patterns of the diversity of macrofauna affected by fish farming and compare them with theP-R model. Then we comment the role of wild fish on modifying macrofauna diversity patterns in sediments affected by fish farming. Finally, we explain the importance of the macrofauna diversity in the ecosystem functioning and we give some recommendations to assess functional diversity related to relevant processes at ecosystem level.

\section{Spatial Patterns in Benthic Macrofauna Diversity Caused by Fish Farming}

Fish farming has similar effects on the benthos than other sources of organic enrichment, producing detrimental conditions derived from oxygen depletion and anaerobic metabolism, leading to changes in benthic diversity [53 and cites therein]. The deposition rate of $\mathrm{OM}$ derived from fish farming ultimately modulates the diversity patterns of the benthic communities in these areas [5,7,9,11]. OM deposition rates derived from aquaculture show an exponential decrease with distance from fish farms [9,54,55], which limits the extent of the perturbation to an area close to the fish cages $[4,56,57]$. The deposition rate is determined by related parameters of the farm (cultured species, feed used, biomass of fish in the farm) and the hydrodynamics of the site (current strength and the variability of current strength and direction) [58-61].

The hydrodynamics of the site will also determine the spatial extent of the enrichment gradient. Low current velocities will cause most of the OM to settle underneath the footprint of the farm (even at very deep sites) [54], higher current strengths will cause the OM to be deposited away from the farm while variations in current strengths will cause the OM to be deposited over larger areas at lower deposition rates [62]. Another important characteristic of OM deposition associated with fish farming is that $\mathrm{OM}$ deposition rates will vary with the farm cycle in the cases where the fish production is not continuous along time. This is the case, for example, of salmon farming, where OM deposition rates rise as the fish grow and require more food [7].

The diversity patterns of macrofauna community derived from fish farming have been widely studied worldwide [7,8,10,62-69]. Following gradients of increasing organic enrichment benthic communities become less diverse, exhibit a lower biomass and a higher proportion of deposit feeders $[44,70,71]$. This is because as oxygen concentration decreases in the sediment, there is a shift towards a few opportunistic/tolerant/r-selected species, which usually have a small body size. Among the major taxa that compose macrofauna, malacostaca crustaceans, followed by bivalves and gastropods, are the most sensitive group to changes produced by oxygen depletion [72]. As regards 
polychaetes, there are both sensitive and tolerant species. Spionids, and specially Capitellids, are the most tolerant families of polychaetes [70]. Among them, Capitella spp. is regarded as the quintessential indicator of oxygen depletion $[44,71,73]$.

The gradient derived from organic enrichment caused by aquaculture, in general terms, coincides with the successional trend shown by the P-R model. In addition, in some studies dealing with sediments impacted by fish farming, the trend of abundance, biomass, species richness and $H$ ' clearly matched with the P-R model $[4,10,24,74,75]$. However, in other studies the observed trends differed from the P-R model to some extent, finding no increase in species richness or $H^{\prime}$ ' at a medium level of organic enrichment $[8,11,56,76,77]$. The fact that in some cases community descriptors indices did not follow the exact trend defined by the P-R model may be due to different reasons. One reason could be the use of a low number of sampling points to characterize the gradient, thus not giving enough resolution to detect maximums of some of the community descriptors at intermediate levels. Another reason could be that the organic enrichment level was not sufficient to show the whole gradient. Moreover, the response of macrofauna to fish farm wastes may also be influenced by sediment characteristics. For example, it has been observed that the P-R model describes changes in species composition in communities inhabiting silty sediment better that in coarser sediments [78].

Regardless of the trends followed by community descriptors, it is clear that communities do not tend to follow a linear and proportional response to OM deposition rate, as it happens with the buildup of toxic by-products of anaerobic metabolism [79]. Biological systems, such as communities, are more likely to resist the perturbation until a threshold is reached, above which serious changes are produced [80] (Figure 2B). The P-R model has been expanded by defining lower and upper thresholds for the biogeochemical parameters total organic carbon, dissolved oxygen and sulfide concentrations and redox potential corresponding to the response of the benthic communities in coastal and marine regions [46,47,81].

Even though these thresholds help us to improve our forecasting capacity of benthic diversity patterns, it is hard to define universal thresholds for all sediments. That is to say, two areas with the same concentration of some biogeochemical parameters may show different benthic diversity and status. This is because there are some sediment characteristics such as the grain size, sediment type (carbonate or non-biogenic), natural sedimentation regime and habitat type, that highly influences the benthic community assemblages.

In the case of the grain size, fine-grained sediments show a lesser space between particles than coarse-grain sediments. This influences the exchange rate of pore water and water from the water column, which, in turn, has important consequences for the recycling of oxygen in the pore water [18]. Thus oxygen is more likely to be depleted in fine than in coarse sediments, and so, under the same OM sedimentation rate fine sediments are expected to suffer more hypoxic events.

In the case of the sediment type, non-biogenic sediments usually have a higher concentration of reactive iron compared with carbonate sediments [3]. Since iron has a capacity to buffer the toxicity of dissolved sulfides[42], fauna inhabiting non-biogenic sediments will resist organic enrichment better than those inhabiting carbonate sediments. Therefore, sediments with different grain sizes and types may favor or hinder the toxicity produced by the reduced conditions due to organic enrichment, indirectly modifying macrofauna diversity and structure [3,66,82]. 
The natural sedimentation regime is also an important variable to take into account. Areas that naturally have greater sedimentation regime are likely to cope better in OM enrichment conditions, since the benthic communities are pre-adapted to high organic inputs [49].

Diversity patterns of macrofauna influenced by fish farming have been mostly studied in "bare"/non-vegetated habitats (e.g., [4,8,24,74]). Vegetated habitats influence macrofauna assemblages, leading to a different structure from that seen in non-vegetated areas [83,84]. Therefore, in this type of sediments diversity patterns under the influence of fish farming may differ from the P-R model. Recently, some studies have dealt with this issue in two types of vegetated sediments, Posidonia oceanica meadows and Maërl beds [11,62,66,85,86].

$P$. oceanica meadows are a common habitat in the Mediterranean Sea, where this species is endemic [87]. Under the influence of fish farming, diversity and other community descriptors do not seem to follow the P-R model in this habitat, showing no significant variations between impacted and reference sites in most of the cases $[66,85,86]$. These observations could be due to the fact that the OM input derived from fish farming was not large enough to produce major changes in the macrofauna parameters. This is understandable since $P$. oceanica is considered to be a sensitive species to organic enrichment sources such as fish farming [88-90]. Accordingly, in these studies, P. oceanica was present even in the sampling stations close to the fish farms.

To understand whether the cause of different diversity patterns in P. oceanica meadows are due to the habitat identity, to low deposition rates or to both, experiments should be complemented with measurements of deposition rates of OM. This is an example of the importance of knowing, not just the distance to the farm, but also the deposition rates of $\mathrm{OM}$ when studying the changes in benthic communities.

Maërl beds are also a vegetated habitat formed by the accumulation of unattached coralline red algae. This habitat is commonly found in zones with strong currents between 15 and $60 \mathrm{~m}$ depth, approximately [91]. Despite being quite a common habitat, to the best of our knowledge only two studies have dealt with changes in the diversity patterns of macrofauna due to fish farming in Maërl beds $[11,62]$. These studies have revealed that most community descriptors (including diversity) may not show maximums at intermediate disturbance levels.

In one of these studies the deposition rate of OM were measured and revealed that the deposition rate below the fish farm was significantly greater than the basal deposition rate [11]. Thus, below the fish farms coralline algae were mostly dead [11,62]. Due to the small number of studies, more research on diversity patterns of macrofauna is necessary on vegetated sediments, to ensure if the patterns shown in these studies are widespread.

In summary, under the influence of fish farming, macrofauna follows the general trends of diversity and other community parameters defined in the P-R model, but these trends can vary according to sediment local characteristics (i.e. grain size, sediment type, basal conditions and habitat type). In order to have a better forecasting of the diversity patterns in different sediments affected by fish farming, different thresholds should be calculated according to the sediment local characteristics. To do this, more research effort on merging OM deposition rates, sediment local characteristics and macrofauna diversity patterns should be carried out. 


\section{Temporal Patterns in Benthic Macrofauna Diversity after Fish Farm Abatement}

The chemical conditions of the sediment after the cessation of the fish farming activity can be restored in a relatively short period of time, even though the recovery of the communities inhabiting the sediment is expected to be slower [65]. This is due to fact that the recruitment of less pollution-tolerant species can only take place after reestablishment of non-polluted conditions in the sediment [50]. In this manuscript, we will use the term "sediment recovery" to refer to the recovery of the macrofauna community.

Seabed recovery after the cessation of fish farm activity shows a high variation among different regions around the world. Some studies found a rapid recovery lasting from few [64,92] to several months [7,49], while in most takes years [2,48,50,51,65,93-96]. The potential of the benthic community to recover after organic enrichment abatement depends on abiotic and biotic factors, as well as on natural sedimentation regime, that determine the species composition within the community and on the tolerance among these species of hypoxia and anoxia [72,97]. Abiotic factors include: depth, topography, current velocity and direction, water temperature, cultured species and composition of feed, [51,93], while biotic factors include: recruitment (larvae supply), competition and ratio of opportunistic species among others [64,98].

In this sense, the recovery of sediments (either defaunated or with a degraded community) after periods of hypoxia is quicker in open coastal areas than in sheltered ones [93]. As for the spatial diversity patterns, natural sedimentation regime also affects the recovery of the sediments. Sediments with a natural high OM load are expected to hold communities with a greater proportion of opportunistic species with shorten life cycles and higher tolerance to oxygen depletion compared to more oligotrophic sediments [66]. Opportunists are the initial colonizers of impacted sediments after the perturbation has ceased [98]. Considering that the colonization of impacted areas is mainly performed with the communities of adjacent areas [99], the species of sediments with a natural high OM load are more likely to rapidly recolonize the impacted areas after the cessation of the disturbance. Therefore, sediments with a natural high OM load may have a natural resilience to overcome organic enrichment episodes [49]. These are some examples that show us how important it is to take into account the baseline conditions of the area in order to better predict recovery [25].

According to Pearson and Rosenberg [44], the temporal pattern of recovery of sediments is similar to the established successional stages of the P-R model along a spatial gradient of organic enrichment, but with unpredictable intermediate stages. This is also the case for sediments after fish farm cessation, where the diversity and structure of the macrofauna community match the trend of the P-R model for the initial and final stages, but not for intermediate stages [48-51]. This unpredictability of intermediate stages of recovery may be due to secondary disturbances [48,51].

Secondary disturbances can be intrinsic, such as the increase in organic material due to exploitation of sedimented nutrients by algal production [48], or extrinsic due to other sources of external perturbation, such as the import of OM [50,51]. The higher variability in the temporal pattern of succession may be due to the fact that transitory communities show a lower diversity and a more simple functional structure than undisturbed communities [51]. Thus, transitory communities can be less resilient to environmental shifts compared with undisturbed communities [100,101]. 
Improving our understanding on benthic recovery could contribute to better manage fish farming by helping to establish optimized fallowing periods between production cycles. More importantly, it would help us to predict the changes that occur during farming so that overloading of the sediment, i.e. defaunation or polluted community stages can be prevented. Furthermore, examining the dynamics of benthic recovery could allow us to predict possible catastrophic shifts [102]. For example, a shift towards a different community than the previous one before the fish farm activity began [96]. More research should focus on studying the dynamics of benthic recovery, identifying the factors that produce secondary disturbances during recovery processes and comprehending the way that the secondary disturbances affect recovery dynamics.

\section{Wild Fish Modulate the Benthic Effects of Fish Farming on Macrofauna Diversity Patterns}

Fish cages, as any other floating object in the sea, tend to aggregate wild fish in their vicinities [103-109], an effect which has been reported in many parts of the world [103,104,110-112]. The attraction of wild fish to fish cages is enhanced by the fact that wild fish consume fish feed, feces or substances derived from the feeding of the cultured fish [55,113-115]. Hence, fish farms can hold up to 40 tons of wild fish [107,108] and abundances 20 times greater than in natural conditions [104] (Figure 3). Thus, wild fish may play a substantial role on modulating the effects of fish farming on the benthos and so, on the diversity patterns of macrofauna. Despite this fact, very little attention has been paid to this issue.

Figure 3. Picture showing wild fish aggregation in a fish farm in the Mediterranean Sea (Spain).

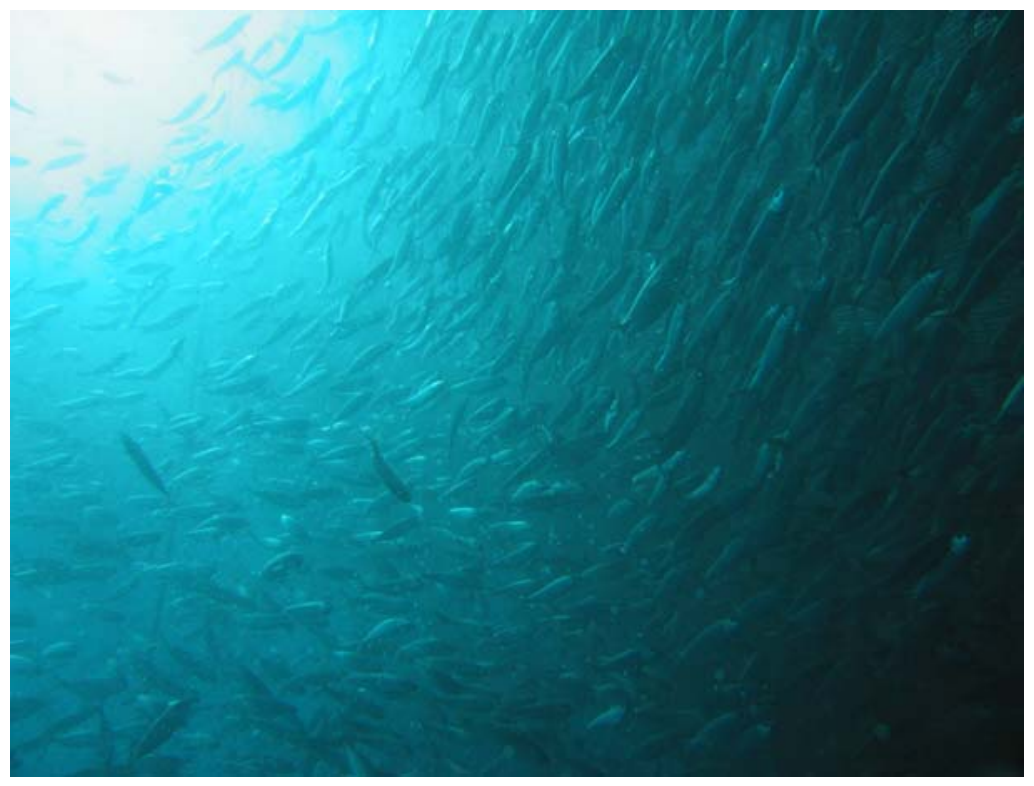

The most obvious effect of wild fish related with aquaculture environmental effects is the consumption of fish farm wastes. In the few studies that have dealt with this issue it has been found that, in the water column, wild fish can consume a substantial part (between 80 and 40\%) of the total wastes released by fish farming $[55,113,115]$. So it is expected that wild fish indirectly modulates macrofauna diversity patterns by diminishing organic enrichment conditions derived from fish 
farming. Wild fish abundance and biomass varies greatly among locations [103,107,108,110], hence the extent to which wild fish modulate macrofauna diversity is expected to be also greatly variable among fish farms.

On the other hand, wild fish can also modulate the macrofaunal diversity and structure in a direct way. Demersal and benthic wild fish when feeding may have several effects on the benthic system, not only arising from their predation on the benthic fauna, but also from the consumption of OM on the seabed and resulting bioturbation of the sediment [116]. Wild fish, by consuming organic wastes and bioturbating the sediments, can ameliorate the effects of organic reduced/anoxic conditions due to organic enrichment and increasing mineralization rates $[115,116]$. These processes improve the sediment chemical status by increasing the oxygen supply to the sediments and by diminishing toxic metabolites derived from anoxic metabolism. Moreover, wild fish that feed on macrofauna community, decrease macrofauna tolerant species density, such as Capitellidae, increasing the evenness among species of the community and so the $H^{\prime}$ [115]. This behavior of wild fish has been observed in locations with sheltered conditions $[115,116]$.

However, in more open water locations, demersal and benthic wild fish do not have a significant effect on the benthic community [117]. This may be because, at these locations, the low waste sedimentation rate that reaches the benthos prevents wild fish attraction.

In summary, associated wild fish can influence macrofauna diversity patterns by diminish organic enrichment derived from fish farming in two ways: (1) indirectly, in the water column, by decreasing the deposition rates of OM to the benthic system and (2) directly, in the sea bed, by consuming fish farm wastes, predation and bioturbation. Due to the limited number of works studying these issues, more experiments are needed in order to provide more robust estimates of the effect of wild fish in reducing deposition rates of $\mathrm{OM}$ and to better understand how wild fish modulate macrofauna benthic diversity and structure and the drivers that influence these patterns.

\section{Assessing Loss on Ecosystem Functioning due to the Alteration of Diversity in Sediments Influenced by Fish Farming}

Diversity is influenced by processes in the ecosystem such as disturbances, but at the same time, diversity influences the performance of ecosystem functions [118]. Thus, the alterations in the macrofauna diversity caused by fish farming may have important consequences in ecosystem functions, such as the mineralization of OM.

Macrofauna communities that exhibit a natural diversity, have a range of species with different biology, and so with different active biological transport traits $[119,120]$. Conversely, sediments affected by organic enrichment sources, such as fish farming, show less diverse macrofauna communities mainly composed by small opportunistic species with lower active biological transport activity [44,96,121]. This results in decreased metabolic capacity of the sediment, which may not be able to put up with the high OM loads derived from the fish farming activity, and may result in increased accumulation of organic waste products [122].

Of special relevance for the environmental management of aquaculture is to consider how the alteration of benthic diversity affects the metabolic capacity of the sediment, in order to maintain a community able to put up with the increased OM loads derived from the fish farming activity. 
Concerning the P-R model, the maximum active biological transport activity of macrofauna species, as regards traits and sediment depth, refers to the normal stage [44,73]. Accordingly, this stage is the one which has the widest oxic layer in the sediment. This matches with Hargrave et al. [81], which related the normal stage of the P-R model to the highest levels of the species diversity and redox potential. Similarly, models based on the macrofauna diversity patterns along OM gradients have shown diversity to be greater with lower OM loads [46,47] (Figure 1B).

Even though communities at the normal stage are expected to have a maximum performance of the ecosystem processes, a decrease in the diversity does not necessarily imply a decrease in the performance of a specific ecosystem processes [123]. Ecosystem processes may be more dependent on functional diversity than on species diversity [124,125]. This is because there may be functionally equivalent species, and so the disappearance of some of these species may not alter the performance of a specific ecosystem function notably [126].

Nevertheless, different species may have different active biological transport traits that may contribute to a different extent to the transport of electron acceptors between the water column and the porewater [124,127]. Among the species that form a community, keystone species have a great importance since they have a disproportionate effect in the maintenance of community structure and ecosystem functioning [127-129]. Because of this, diversity and functional diversity have a positive, but not linear, relationship with ecosystem functioning [123,130].

Following this reasoning, in areas affected by aquaculture, if we are aiming to keep ecosystem processes at a viable rate, the best strategy to assess the status of ecosystem processes may not be to use traditional diversity measures, such as species richness and $H^{\prime}$. For example, the loss of just one species may not produce a sensitive decrease in the overall community diversity, but it may have different relevance for the ecosystem processes. If the species lost is functionally equivalent with another one, it may not imply a notable decrease in the performance of a given ecosystem process $[123,131]$. However, if the species lost is a keystone species, its removal can have a notable decrease in the performance of the process [132] (Figure 4). Similarly, as regards benthic recovery after the cessation of the fish farming, the restoration of ecosystem functions may be a more useful indicator of recovery than the community equivalence with unpolluted areas [121].

Few studies have dealt with the effects of fish farming on the ecosystem functioning $[11,51,96,121,133]$. In these studies, one or more functional traits have been assigned to each species and then the changes on functional diversity have been compared according to the level of fish farm impact. All these studies have not focused on a particular ecosystem process and so they have given the same importance to each trait. To the best of our knowledge, only Papageorgiou et al. [133] have really employed active biological transport traits in the delineation of functional groups. 
Figure 4. A simplified example of the relative importance that each species could have for a given ecosystem function, and the differential loss of performance of an ecosystem function due to the extinction of different species. (A) This example is based on a macrofauna community composed of eight species which are assigned to different functional groups according to their active biological transport traits. (B) Different traits of active biological transport enhance the metabolic capacity of the sediment to a different extent. Hence, the extinction of different species may affect ecosystem functioning differently according to the type and uniqueness of the trait of the species lost. Note that the loss of species richness, per se, does not necessarily imply a decrease in the performance of a given ecosystem process [123,131]. But, some species may have a disproportionate influence relative to others, and their removal can incur a notable decrease in the performance of that process [132].

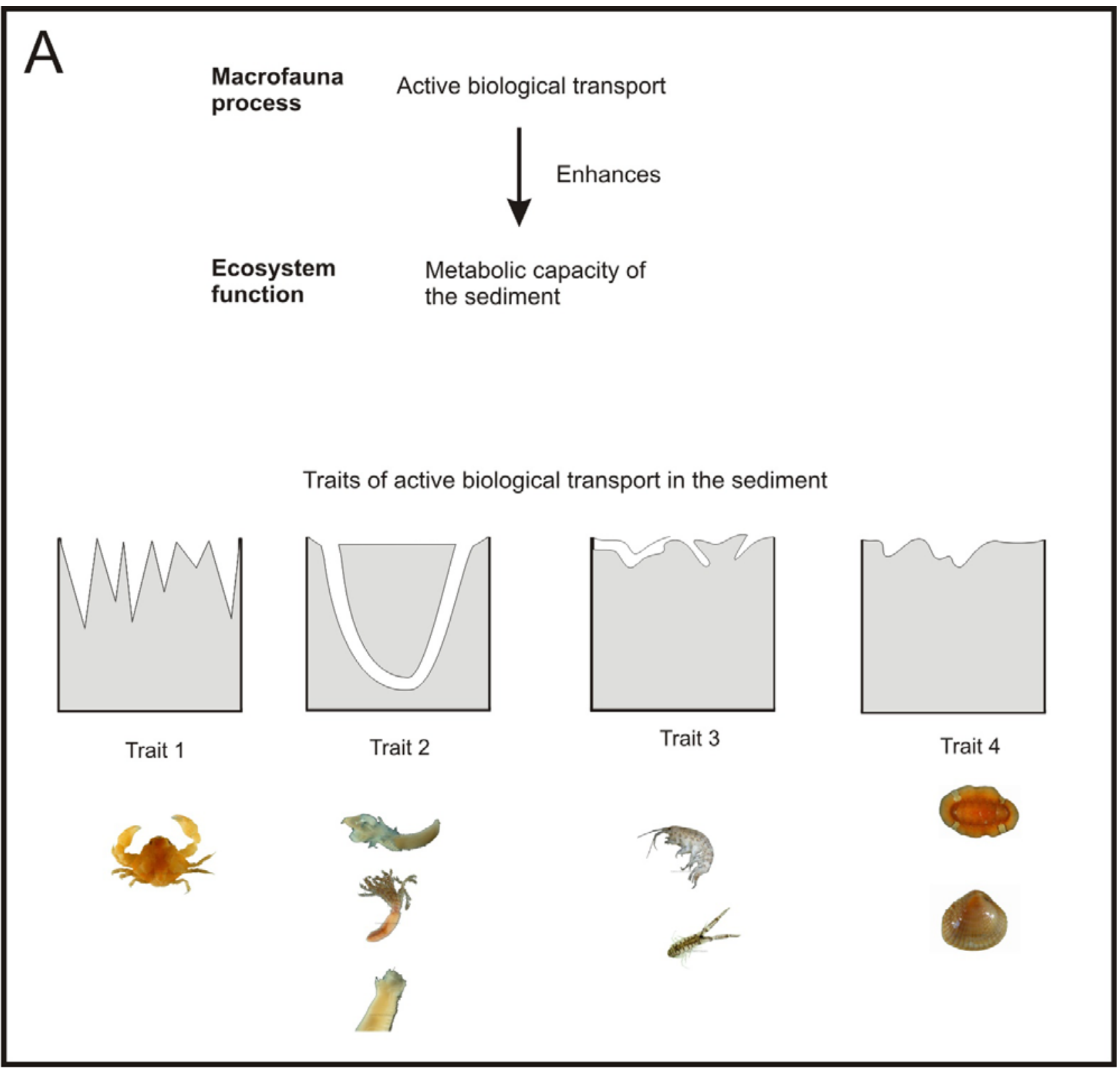


Figure 4. Cont.

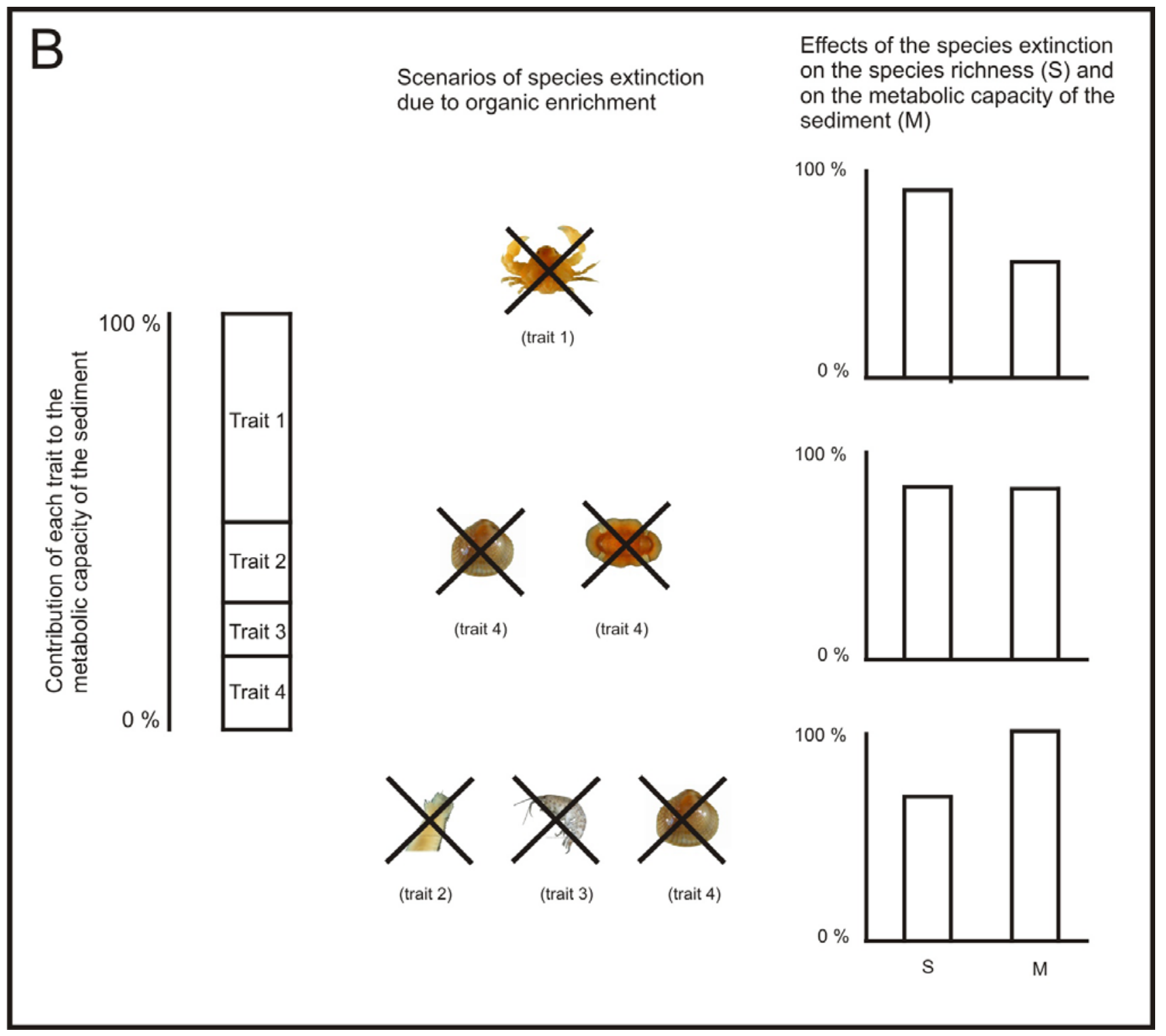

The work from Papageorgiou et al. [133] could be a good starting point to develop a measure of functional diversity of the macrofauna community that allows us to assess the performance of a specific relevant ecosystem process, such as, the metabolic capacity of the sediment. Let us call this measure performance of functional diversity (PFD). A way of developing such a measure could be by addressing the following issues: (1) identification of which species and traits have a large influence on a specific ecosystem process, (2) development of functional response groups based on these traits [134] and (3) estimating the relative importance of each functional group to the specific ecosystem process (Figure 4).

There has already been some work done on the identification of the species relevant traits related to the metabolic capacity of the sediment [135], but more experiments may be necessary for some species whose traits are not clearly defined. Then, the species, according to their relevant traits, could be included in their corresponding functional group. It would also be important to identify the presence of keystone species, if any. Once keystone species have been identified; each keystone could be treated as 
a separate functional group. After the functional groups have been developed, it would be desirable to quantify the relative importance of each functional group for a given ecosystem process by performing specific experiments for this task [124,136].

Then, the measure of PFD could be developed under a similar conceptual basis as functional diversity (FD) defined by Petchey and Gaston [137] , in the sense that it takes into account the relative importance of each functional group to calculate functional diversity. However, in our case, it would be desirable that the measure obtained would be related to an estimation of the performance of the ecosystem process.

Thereby, it would be possible to assess the status of the ecosystem functioning for a given process by studying the composition and structure of a community and then applying the measure of PFD. Furthermore, "functional" thresholds related to fish farming for a particular macrofauna community could be obtained, i.e. the maximum organic load that a given community can undergo maintaining the metabolic capacity of the sediment at a viable rate.

The same proceeding could be done for other relevant ecosystem processes in order to obtain their respective "functional" thresholds for different macrofauna communities. The use of PFD measures would allow to assess the status of the ecosystem functioning and to predict the decrease in performance of ecosystem processes derived from the alteration of diversity due to fish farming.

Nevertheless, it has to be considered that species with the same specific traits may differ in aspects related with their ecology, and different environmental conditions may affect the rates of their activities differently. Furthermore, species linkages are poorly understood, and removal of one could, directly or indirectly, affect others [132]. The more the spatial and temporal variability increases, more species are needed to ensure a viable performance of ecosystem processes [123].Thus, taking into account that we live in a constantly changing world, as a measure of precaution, it would be recommended to preserve a greater amount of diversity than just the exact estimated quantity to maintain ecosystem functions.

\section{Conclusions}

Macrofauna diversity patterns under the influence of fish farming have been studied to some extent, but further research is needed in order to have a more accurate forecasting capacity of these patterns. On the one hand, more studies merging OM deposition rates, sediment local characteristics and macrofauna diversity patterns, should be performed. Benthic succession should be investigated more thoroughly in order to try to disentangle the different drivers that make diversity patterns so unpredictable at transitory stages. Also, the role of wild fish in modulating macrofauna diversity patterns (directly and indirectly) should be studied more deeply in order to have a better understanding of these processes. On the other hand, it would be desirable to be able to measure functional diversity related to processes relevant at an ecosystem level. To do this, we should create functional groups based on relevant traits linked to ecosystem processes and take into account the relative importance of each functional group in a given ecosystem process. Advances in these directions could help environmental protection agencies to improve their management strategies to guarantee a good status of the diversity and ecosystem functioning of sediments influenced by fish farming. 


\section{Acknowledgments}

C. S. would like to thank the guest editor Cristina Munari for the chance to participate in this special issue. Three anonymous reviewers provided comments that significantly improved this work.

\section{References}

1. FAO. The State of World Fisheries and Aquaculture 2006; Food and Agricultural Organization: Rome, Italy, 2007.

2. Gowen, R.J.; Bradbury, N.B. The ecological impact of salmonid farming in coastal waters-A review. Oceanogr. Mar. Biol. 1987, 25, 563-575.

3. Holmer, M.; Wildfish, D.; Hargrave, B. Organic enrichment from marine finfish Aquaculture and effects on sediment biogeochemical processes. In Environmental Effects of Marine Finfish Aquaculture; Hargrave, B.T., Ed.; Springer: Berlin, Germany, 2005; pp. 181-206.

4. Brown, J.R.; Gowen, R.J.; Mclusky, D.S. The effect of salmon farming on the benthos of a Scottish Sea Loch. J. Exp. Mar. Biol. Ecol. 1987, 109, 39-51.

5. Hall, P.O.J.; Anderson, L.G.; Holby, O.; Kollberg, S.; Samuelsson, M.O. Chemical fluxes and mass balances in a marine fish cage farm .1. Carbon. Mar. Ecol. Prog. Ser. 1990, 61, 61-73.

6. Sanz-Lazaro, C.; Marin, A. Assessment of finfish aquaculture impact on the benthic communities in the Mediterranean Sea. In Aquaculture I. Dynamic Biochemistry, Process Biotechnology and Molecular Biology 2; Russo, R., Ed.; Global Science Books: Ikenobe, Japan, 2008; pp. 21-32.

7. Brooks, K.M.; Mahnken, C.V.W. Interactions of Atlantic salmon in the Pacific northwest environment II. Organic wastes. Fisheries Research 2003, 62, 255-293.

8. Vita, R.; Marin, A. Environmental impact of capture-based bluefin tuna aquaculture on benthic communities in the western Mediterranean. Aquacult. Res. 2007, 38, 331-339.

9. Holmer, M.; Marbà, N.; Díaz-Almela, E.; Duarte, C.M.; Tsapakis, M.; Danovaro, R. Sedimentation of organic matter from fish farms in oligotrophic Mediterranean assessed through bulk and stable isotope (delta C-13 and delta N-15) analyses. Aquaculture 2007, 262, 268-280.

10. Kutti, T.; Hansen, P.K.; Ervik, A.; Hoisaeter, T.; Johannessen, P. Effects of organic effluents from a salmon farm on a fjord system. II. Temporal and spatial patterns in infauna community composition. Aquaculture 2007, 262, 355-366.

11. Sanz-Lazaro, C.; Belando, M.D.; Marín-Guirao, L.; Navarrete-Mier, F.; Marín, A. Relationship between sedimentation rates and benthic impact on Maërl beds derived from fish farming in the Mediterranean. Mar. Environ. Res. 2011, 71, 22-30.

12. Vita, R.; Marín, A.; Jimenez-Brinquis, B.; Cesar, A.; Marín-Guirao, L.; Borredat, M. Aquaculture of Bluefin tuna in the Mediterranean: Evaluation of organic particulate wastes. Aquacult. Res. 2004, 35, 1384-1387.

13. Holmer, M.; Kristensen, E. Impact of marine fish cage farming on metabolism and sulfate reduction of underlying sediments. Mar. Ecol. Prog. Ser. 1992, 80, 191-201.

14. Sanz-Lázaro, C.; Valdemarsen, T.; Marin, A.; Holmer, M. The effect of temperature on the biogeochemical cycles in marine organic-enriched benthic systems: Implications in a global warming scenario. 2011 (submitted). 
15. Jorgensen, B.B. Mineralization of organic-matter in the sea bed-The role of sulfate reduction. Nature 1982, 296, 643-645.

16. Middelburg, J.J.; Levin, L.A. Coastal hypoxia and sediment biogeochemistry. Biogeosciences 2009, 6, 1273-1293.

17. Emerson, S.; Hedges, J. Sediment diagenesis and benthic flux. In Treatise on Geochemistry; Elderfield, H., Ed.; Elsevier Science: Amsterdam, The Netherlands, 2003; pp. 293-319.

18. Middelburg, J.J.; Duarte, C.M.; Gattuso, J.P. Respiration in coastal benthic communities. In Respiration in Aquatic Ecosystems; Del Giogio, P.A., Williams, P.J., Eds.; Oxford University Press: Chippenham,UK, 2005; pp. 206-224.

19. Dean, R.J.; Shimmield, T.M.; Black, K.D. Copper, zinc and cadmium in marine cage fish farm sediments: An extensive survey. Environmental Pollution 2007, 145, 84-95.

20. Sanz-Lazaro, C.; Navarrete-Mier, F.; Marin, A. Biofilm responses to marine fish farm wastes. Env. Pollut. 2011, 159, 825-832.

21. Davies, I.M.; McHenery, J.G.; Rae, G.H. Environmental risk from dissolved ivermectin to marine organisms. Aquaculture 1997, 158, 263-275.

22. Murray, L.; Bulling, M.; Mayor, D.; Sanz-Lázaro, C.; Paton, G.; Killham, K.; Solan, M. Interactive effects of biodiversity, copper and a chemotherapeutant on marine benthic function. In Proceedings of the World Conference on Marine Biodiversity 2008 (MARBEF), Valencia, Spain, 11-15 November 2008.

23. Pinto, R.; Patricio, J.; Baeta, A.; Fath, B.D.; Neto, J.M.; Marques, J.C. Review and evaluation of estuarine biotic indices to assess benthic condition. Ecol. Indic. 2009, 9, 1-25.

24. Karakassis, I.; Tsapakis, M.; Hatziyanni, E.; Papadopoulou, K.N.; Plaiti, W. Impact of cage farming of fish on the seabed in three Mediterranean coastal areas. Ices J. Mar. Sci. 2000, 57, 1462-1471.

25. Macleod, C.K.; Moltschaniwskyj, N.A.; Crawford, C.M. Evaluation of short-term fallowing as a strategy for the management of recurring organic enrichment under salmon cages. Mar. Pollut. Bull. 2006, 52, 1458-1466.

26. Snelgrove, P.V.R. The biodiversity of macrofaunal organisms in marine sediments. Biol. Conserv. 1998, 7, 1123-1132.

27. Reiss, H.; Kroncke, I. Seasonal variability of benthic indices: An approach to test the applicability of different indices for ecosystem quality assessment. Mar. Pollut. Bull. 2005, 50, 1490-1499.

28. Braeckman, U.; Provoost, P.; Gribsholt, B.; Van Gansbeke, D.; Middelburg, J.J.; Soetaert, K.; Vincx, M.; Vanaverbeke, J. Role of macrofauna functional traits and density in biogeochemical fluxes and bioturbation. Mar. Ecol. Prog. Ser. 2010, 399, 173-186.

29. Aller, R.C. Bioturbation and remineralization of sedimentary organic-matter-effects of redox oscillation. Chem. Geol. 1994, 114, 331-345.

30. Kristensen, E.; Holmer, M. Decomposition of plant materials in marine sediment exposed to different electron accepters $\left(\mathrm{O}^{2-}, \mathrm{NO}^{3-}\right.$, and $\left.\mathrm{SO}_{4}{ }^{2-}\right)$, with emphasis on substrate origin, degradation kinetics, and the role of bioturbation. Geochimica et Cosmochimica Acta. 2001, 65, 419-433. 
31. Ieno, E.N.; Solan, M.; Batty, P.; Pierce, G.J. How biodiversity affects ecosystem functioning: Roles of infaunal species richness, identity and density in the marine benthos. Mar. Ecol. Prog. Ser. 2006, 311, 263-271.

32. Meysman, F.J.R.; Middelburg, J.J.; Heip, C.H.R. Bioturbation: A fresh look at Darwin's last idea. Trends Ecol. Evol. 2006, 21, 688-695.

33. Banta, G.T.; Holmer, M.; Jensen, M.H.; Kristensen, E. Effects of two polychaete worms, Nereis diversicolor and Arenicola marina, on aerobic and anaerobic decomposition in a sandy marine sediment. Aquat. Microb. Ecol. 1999, 19, 189-204.

34. Rysgaard, S.; Thamdrup, B.; Risgaard-Petersen, N.; Fossing, H.; Berg, P.; Christensen, P.B.; Dalsgaard, T. Seasonal carbon and nutrient mineralization in a high-Arctic coastal marine sediment, Young Sound, Northeast Greenland. Mar. Ecol. Prog. Ser. 1998, 175, 261-276.

35. Rowe, G.T.; Clifford, C.H.; Smith, K.L. Benthic nutrient regeneration and its coupling to primary productivity in coastal waters. Nature 1975, 255, 215-217.

36. Jorgensen, B.B. Material flux in the sediment. In Eutrophication in Coastal Marine Ecosystems; Jorgensen, B.B., Richardson, K., Eds.; American Geophysical Union: Washington, DC, USA, 1996; pp. 115-135.

37. Eyre, B.D.; Ferguson, A.J.P. Denitrification efficiency for defining critical loads of carbon in shallow coastal ecosystems. Hydrobiologia 2009, 629, 137-146.

38. Karlson, K.; Bonsdorff, E.; Rosenberg, R. The impact of benthic macrofauna for nutrient fluxes from Baltic Sea sediments. Ambio. 2007, 36, 161-167.

39. Kristensen, E.; Jensen, M.H.; Aller, R.C. Direct measurement of dissolved inorganic nitrogen exchange and denitrification in individual Polychaete (Nereis-virens) burrows. J. Mar. Res. 1991, 49, 355-377.

40. Diaz, R.J.; Rosenberg, R. Spreading dead zones and consequences for marine ecosystems. Science 2008, 321, 926-929.

41. Nixon, S.W. Coastal marine eutrophication-A definition, social causes, and future concerns. Ophelia 1995, 41, 199-219.

42. Azzoni, R.; Giordani, G.; Viaroli, P. Iron-sulphur-phosphorus interactions: Implications for sediment buffering capacity in a mediterranean eutrophic lagoon (Sacca di Goro, Italy). Hydrobiologia 2005, 550, 131-148.

43. Magurran, A.E. Measuring Biological Diversity; Magurran, A.E., Ed.; Blackwell: Oxford, UK, 2004.

44. Pearson, T.H.; Rosenberg, R. Macrobenthic succession in relation to organic enrichment and pollution of the marine environment. Oceanogr. Mar. Biol. Annu. Rev. 1978, 16, 229-311.

45. Whomersley, P.; Huxham, M.; Bolam, S.; Schratzberger, M.; Augley, J.; Ridland, D. Response of intertidal macrofauna to multiple disturbance types and intensities - An experimental approach. Mar. Environ. Res. 2010, 69, 297-308.

46. Hyland, J.; Balthis, L.; Karakassis, I.; Magni, P.; Petrov, A.; Shine, J.; Vestergaard, O.; Warwick, R. Organic carbon content of sediments as an indicator of stress in the marine benthos. Mar. Ecol. Prog. Ser. 2005, 295, 91-103.

47. Magni, P.; Tagliapietra, D.; Lardicci, C.; Balthis, L.; Castelli, A.; Como, S.; Frangipane, G.; Giordani, G.; Hyland, J.; Maltagliati, F.; Pessa, G.; Rismondo, A.; Tataranni, M.; Tomassetti, P.; 
Viaroli, P. Animal-sediment relationships: Evaluating the 'Pearson-Rosenberg paradigm' in Mediterranean coastal lagoons. Mar. Pollut. Bull. 2009, 58, 478-486.

48. Karakassis, I.; Hatziyanni, E.; Tsapakis, M.; Plaiti, W. Benthic recovery following cessation of fish farming: a series of successes and catastrophes. Mar. Ecol.-Progr. Ser. 1999, 184, 205-218.

49. Macleod, C.K.; Moltschaniwskyj, N.A.; Crawford, C.M.; Forbes, S.E. Biological recovery from organic enrichment: Some systems cope better than others. Mar. Ecol. Prog. Ser. 2007, 342, 41-53.

50. Pereira, P.M.F.; Black, K.D.; Mclusky, D.S.; Nickell, T.D. Recovery of sediments after cessation of marine fish farm production. Aquaculture 2004, 235, 315-330.

51. Sanz-Lazaro, C.; Marin, A. Benthic recovery during open sea fish farming abatement in Western Mediterranean, Spain. Mar. Environ. Res. 2006, 62, 374-387.

52. Petchey, O.L.; Gaston, K.J. Functional diversity: Back to basics and looking forward. Ecol. Lett. 2006, 9, 741-758.

53. Mente, E.; Pierce, G.J.; Santos, M.B.; Neofitou, C. Effect of feed and feeding in the culture of salmonids on the marine aquatic environment: A synthesis for European aquaculture. Aquacult. Internat. 2006, 14, 499-522.

54. Kutti, T.; Ervik, A.; Hansen, P.K. Effects of organic effluents from a salmon farm on a fjord system. I. Vertical export and dispersal processes. Aquaculture 2007, 262, 367-381.

55. Sanz-Lazaro, C. Environmental Effects of Aquaculture and Oil Spills; LAP Lambert Academic Publishing: Saarbrücken, Germany, 2010.

56. Aguado-Gimenez, F.; Marin, A.; Montoya, S.; Marin-Guirao, L.; Piedecausa, A.; Garcia-Garcia, B. Comparison between some procedures for monitoring offshore cage culture in western Mediterranean Sea: Sampling methods and impact indicators in soft substrata. Aquaculture 2007, 271, 357-370.

57. Vezzulli, L.; Moreno, M.; Marin, V.; Pezzati, E.; Bartoli, M.; Fabiano, M. Organic waste impact of capture-based Atlantic bluefin tuna aquaculture at an exposed site in the Mediterranean Sea. Esturar. Coast. Shelf Sci. 2008, 78, 369-384.

58. Cromey, C.J.; Nickell, T.D.; Black, K.D. DEPOMOD-Modelling the deposition and biological effects of waste solids from marine cage farms. Aquaculture 2002, 214, 211-239.

59. Gowen, R.J.; Smyth, D.; Silvert, W. Modelling the spatial distribution and loading of organic fish farm waste to the seabed. In Modelling Benthic Impacts of Organic Enrichment from Marine Aquaculture; Hargrave, B.T., Ed.;Dartmouth, Novia Scotia, 1994; pp. 19-30.

60. Jusup, M.; Gecek, S.; Legovic, T. Impact of aquacultures on the marine ecosystem: Modelling benthic carbon loading over variable depth. Ecol. Model. 2007, 200, 459-466.

61. Pérez, O.M.; Telfer, T.C.; Beveridge, M.C.M.; Ross, L.G. Geographical Information Systems (GIS) as a simple tool to aid modelling of particulate waste distribution at marine fish cage sites. Estuar. Coast. Shelf Sci. 2002, 54, 761-768.

62. Hall-Spencer, J.; White, N.; Gillespie, E.; Gillham, K.; Foggo, A. Impact of fish farms on maerl beds in strongly tidal areas. Mar. Ecol.-Progr. Ser. 2006, 326, 1-9.

63. Edgar, G.J.; Davey, A.; Sheperd, C. Application of biotic and abiotic indicators for detecting benthic impacts of marine salmonid farming among coastal regions of Tasmania. Aquaculture 2010, 307, 212-218. 
64. Lu, L.; Wu, R.S.S. Recolonization and succession of marine macrobenthos in organic-enriched sediment deposited from fish farms. Env. Pollut. 1998, 101, 241-251.

65. Macleod, C.K.; Crawford, C.M.; Moltschaniwskyj, N.A. Assessment of long term change in sediment condition after organic enrichment: defining recovery. Mar. Pollut. Bull. 2004, 49, 79-88.

66. Papageorgiou, N.; Kalantzi, I.; Karakassis, I. Effects of fish farming on the biological and geochemical properties of muddy and sandy sediments in the Mediterranean Sea. Mar. Environ. Res. 2010, 69, 326-336.

67. Yokoyama, H. Monitoring, assessment and management of fish farm environments in Japan. Rev. Aquacult. 2010, 2, 154-165.

68. Soto, D.; Norambuena, F. Evaluation of salmon farming effects on marine systems in the inner seas of southern Chile: A large-scale mensurative experiment. J. Appl. Ichthyol. 2004, 20, 493-501.

69. Lee, H.W.; Bailey-Brock, J.H.; Mcgurr, M.M. Temporal changes in the polychaete infaunal community surrounding a Hawaiian mariculture operation. Mar. Ecol. Prog. Ser. 2006, 307, 175-185.

70. Levin, L.A.; Ekau, W.; Gooday, A.J.; Jorissen, F.; Middelburg, J.J.; Naqvi, S.W.A.; Neira, C.; Rabalais, N.N.; Zhang, J. Effects of natural and human-induced hypoxia on coastal benthos. Biogeosciences 2009, 6, 2063-2098.

71. Wu, R.S.S. Hypoxia: From molecular responses to ecosystem responses. Mar. Pollut. Bull. 2002, 45, 35-45.

72. Diaz, R.J.; Rosenberg, R. Marine benthic hypoxia: A review of its ecological effects and the behavioural responses of benthic macrofauna. Oceanogr. Mar. Biol. -Annu. Rev. 1995, 33, 245-303.

73. Rosenberg, R. Marine benthic faunal successional stages and related sedimentary activity. Scientia Marina 2001, 65, 107-119.

74. Edgar, G.J.; Macleod, C.K.; Mawbey, R.B.; Shields, D. Broad-scale effects of marine salmonid aquaculture on macrobenthos and the sediment environment in southeastern Tasmania. J. Exp. Mar. Biol. Ecol. 2005, 327, 70-90.

75. Nickell, L.A.; Black, K.D.; Hughes, D.J.; Overnell, J.; Brand, T.; Nickell, T.D.; Breuer, E.; Harvey, S.M. Bioturbation, sediment fluxes and benthic community structure around a salmon cage farm in Loch Creran, Scotland. J. Exp. Mar. Biol. Ecol. 2003, 285, 221-233.

76. Carroll, M.L.; Cochrane, S.; Fieler, R.; Velvin, R.; White, P. Organic enrichment of sediments from salmon farming in Norway: Environmental factors, management practices, and monitoring techniques. Aquaculture 2003, 226, 165-180.

77. Mayor, D.J.; Zuur, A.F.; Solan, M.; Paton, G.I.; Killham, K. Factors affecting benthic impacts at Scottish fish farms. Environ. Sci. Technol. 2010, 44, 2079-2084.

78. Karakassis, I. Environmental impacts of aquaculture in the Mediterranean. In Proceedings of the SHoCMed, Tangiers, Morocco, October 2009.

79. Gray, J.S. The Ecology of Marine Sediments; Cambridge University Press: Cambridge, UK, 1981. 
80. Scheffer, M.; Carpenter, S.; Foley, J.A.; Folke, C.; Walker, B. Catastrophic shifts in ecosystems. Nature 2001, 413, 591-596.

81. Hargrave, B.T.; Holmer, M.; Newcombe, C.P. Towards a classification of organic enrichment in marine sediments based on biogeochemical indicators. Mar. Pollut. Bull. 2008, 56, 810-824.

82. Valdemarsen, T.; Kristensen, E.; Holmer, M. Metabolic threshold and sulfide-buffering in diffusion controlled marine sediments impacted by continuous organic enrichment. Biogeochemistry 2009, 95, 335-353.

83. Grall, J.; Le Loc'h, F.; Guyonnet, B.; Riera, P. Community structure and food web based on stable isotopes (delta N-15 and delta C-13) analysis of a North Eastern Atlantic maerl bed. J. Exp. Mar. Biol. Ecol. 2006, 338, 1-15.

84. Mills, V.S.; Berkenbusch, K. Seagrass (Zostera muelleri) patch size and spatial location influence infaunal macroinvertebrate assemblages. Esturar. Coast. Shelf Sci. 2009, 81, 123-129.

85. Apostolaki, E.T.; Tsagaraki, T.; Tsapaki, M.; Karakassis, I. Fish farming impact on sediments and macrofauna associated with seagrass meadows in the Mediterranean. Esturar. Coast. Shelf Sci. 2007, 75, 408-416.

86. Terlizzi, A.; De Falco, G.; Felline, S.; Fiorentino, D.; Gambi, M.C.; Cancemi, G. Effects of marine cage aquaculture on macrofauna assemblages associated with Posidonia oceanica meadows. Ital. J. Zool. 2010, 77, 362-371.

87. Bethoux, J.P.; Copinmontegut, G. Biological fixation of atmospheric nitrogen in the Mediterranean-Sea. Limnol. Oceanogr. 1986, 31, 1353-1358.

88. Díaz-Almela, E.; Marba, N.; Alvarez, E.; Santiago, R.; Holmer, M.; Grau, A.; Mirto, S.; Danovaro, R.; Petrou, A.; Argyrou, M.; Karakassis, I.; Duarte, C.M. Benthic input rates predict seagrass (Posidonia oceanica) fish farm-induced decline. Mar. Pollut. Bull. 2008, 56, 13321342.

89. Holmer, M.; Argyrou, M.; Dalsgaard, T.; Danovaro, R.; Diaz-Almela, E.; Carlos, M.D.E.; Frederiksen, M.; Grau, A.; Karakassis, I.; Marba, N.; Mirto, S.; Perez, M.; Pusceddu, A.; Tsapakis, M. Effects of fish farm waste on Posidonia oceanica meadows: Synthesis and provision of monitoring and management tools. Mar. Pollut. Bull. 2008, 56, 1618-1629.

90. Pergent-Martini, C.; Boudouresque, C.F.; Pasqualini, V.; Pergent, G. Impact of fish farming facilities on Posidonia oceanica meadows: a review. Mar. Ecol-Evol. Persp. 2006, 27, 310-319.

91. Foster, M.S. Rhodoliths: Between rocks and soft places. J. Phycol. 2001, 37, 659-667.

92. Ritz, D.A.; Lewis, M.E.; Shen, M. Response to organic enrichment of infaunal macrobenthic communities under salmonid seacages. Mar. Biol. 1989, 103, 211-214.

93. Kraufvelin, P.; Sinisalo, B.; Leppakoski, E.; Mattila, J.; Bonsdorff, E. Changes in zoobenthic community structure after pollution abatement from fish farms in the Archipelago Sea (N. Baltic Sea). Mar. Environ. Res. 2001, 51, 229-245.

94. Lumb, C.M. Self-pollution by Scottish salmon farms. Mar. Pollut. Bull. 1989, 20, 375-379.

95. Pohle, G.; Frost, B.; Findlay, R. Assessment of regional benthic impact of salmon mariculture within the Letang Inlet, Bay of Fundy. Ices J. Mar. Sci. 2001, 58, 417-426.

96. Villnas, A.; Perus, J.; Bonsdorff, E. Structural and functional shifts in zoobenthos induced by organic enrichment-Implications for community recovery potential. J. Sea Res. 2011, 65, 8-18. 
97. Dernie, K.M.; Kaiser, M.J.; Warwick, R.M. Recovery rates of benthic communities following physical disturbance. J. Anim. Ecol. 2003, 72, 1043-1056.

98. Lu, L.; Wu, R.S.S. An experimental study on recolonization and succession of marine macrobenthos in defaunated sediment. Mar. Biol. 2000, 136, 291-302.

99. Guerra-Garcia, J.M.; Garcia-Gomez, J.C. Recolonization of defaunated sediments: Fine versus gross sand and dredging versus experimental trays. Esturar. Coast. Shelf Sci. 2006, 68, 328-342.

100. Loreau, M.; Naeem, S.; Inchausti, P.; Bengtsson, J.; Grime, J.P.; Hector, A.; Hooper, D.U.; Huston, M.A.; Raffaelli, D.; Schmid, B.; Tilman, D.; Wardle, D.A. Biodiversity and ecosystem functioning: Current knowledge and future challenges. Science 2001, 294, 804-808.

101. Tilman, D.; Downing, J.A. Biodiversity and stability in grasslands. Nature 1994, 367, 363-365.

102. Van Nes, E.H.; Scheffer, M. Slow recovery from perturbations as a generic indicator of a nearby catastrophic shift. Amer. Naturalist. 2007, 169, 738-747.

103. Boyra, A.; Sanchez-Jerez, P.; Tuya, F.; Espino, F.; Haroun, R. Attraction of wild coastal fishes to an Atlantic subtropical cage fish farms, Gran Canaria, Canary Islands. Environ. Biol. Fish. 2004, 70, 393-401.

104. Dempster, T.; Sanchez-Jerez, P.; Uglem, I.; Bjorn, P.A. Species-specific patterns of aggregation of wild fish around fish farms. Esturar. Coast. Shelf Sci. 2010, 86, 271-275.

105. Carss, D.N. Concentrations of wild and escaped fishes immediately adjacent to fish farm cages. Aquaculture 1990, 90, 29-40.

106. Dempster, T.; Sanchez-Jerez, P.; Bayle-Sempere, J.T.; Gimenez-Casalduero, F.; Valle, C. Attraction of wild fish to sea-cage fish farms in the south-western Mediterranean Sea: Spatial and short-term temporal variability. Mar. Ecol. Prog. Ser. 2002, 242, 237-252.

107. Dempster, T.; Sanchez-Jerez, P.; Bayle-Sempere, J.; Kingsford, M. Extensive aggregations of wild fish at coastal sea-cage fish farms. Hydrobiologia 2004, 525, 245-248.

108. Dempster, T.; Uglem, I.; Sanchez-Jerez, P.; Fernandez-Jover, D.; Bayle-Sempere, J.; Nilsen, R.; Bjorn, P.A. Coastal salmon farms attract large and persistent aggregations of wild fish: An ecosystem effect. Mar. Ecol. Prog. Ser. 2009, 385, 1-14.

109. Tuya, F.; Sanchez-Jerez, P.; Dempster, T.; Boyra, A.; Haroun, R.J. Changes in demersal wild fish aggregations beneath a sea-cage fish farm after the cessation of farming. J. Fish. Biol. 2006, 69, 682-697.

110. Dempster, T.; Fernandez-Jover, D.; Sanchez-Jerez, P.; Tuya, F.; Bayle-Sempere, J.; Boyra, A.; Haroun, R.J. Vertical variability of wild fish assemblages around sea-cage fish farms: Implications for management. Mar. Ecol. Prog. Ser. 2005, 304, 15-29.

111. Sudirman, H.H.; Jompa, J.; Iswahyudin, Z.; McKinnon, A.D. Wild fish associated with tropical sea cage aquaculture in South Sulawesi, Indonesia. Aquaculture 2009, 286, 233-239.

112. Dempster, T.; Sanchez-Jerez, P.; Tuya, F.; Fernandez-Jover, D.; Bayle-Sempere, J.; Boyra, A.; Haroun, R. Coastal aquaculture and conservation can work together. Mar. Ecol. Prog. Ser. 2006, 314, 309-310.

113. Felsing, B.; Glencross, B.; Telfer, T. Preliminary study on the effects of exclusion of wild fauna from aquaculture cages in a shallow marine environment. Aquaculture 2005, 243, 159-174.

114. Fernandez-Jover, D.; Jimenez, J.A.L.; Sanchez-Jerez, P.; Bayle-Sempere, J.; Casalduero, F.G.; Lopez, F.J.M.; Dempster, T. Changes in body condition and fatty acid composition of wild 
Mediterranean horse mackerel (Trachurus mediterraneus, Steindachner, 1868) associated to sea cage fish farms. Mar. Environ. Res. 2007, 63, 1-18.

115. Vita, R.; Marín, A.; Madrid, J.A.; Jimenez-Brinquis, B.; Cesar, A.; Marín-Guirao, L. Effects of wild fishes on waste exportation from a Mediterranean fish farm. Mar. Ecol.-Progr. Ser. 2004, 277, 253-261.

116. Katz, T.; Herut, B.; Genin, A.; Angel, D.L. Gray mullets ameliorate organically enriched sediments below a fish farm in the oligotrophic Gulf of Aqaba (Red Sea). Mar. Ecol. Prol. Ser. 2002, 234,205-214.

117. Sanz-Lazaro, C.; Belando, M.D.; Navarrete-Mier, F.; Marin, A. Effects of wild fish and motile epibenthic invertebrates on the benthos below an open water fish farm. Estuar. Coast. Shelf Sci. 2011, 91, 216-223.

118. Gamfeldt, L.; Hillebrand, H. Biodiversity effects on aquatic ecosystem functioning-Maturation of a new paradigm. Int. Rev. Hydrobiol. 2008, 93, 550-564.

119. Aller, R.C.; Aller, J.Y. The effect of biogenic irrigation intensity and solute exchange on diagenetic reaction rates in marine sediments. J. Mar. Res. 1998, 56, 905-936.

120. Austen, M.C.; Lambshead, P.J.D.; Hutchings, P.A.; Boucher, G.; Snelgrove, P.V.R.; Heip, C.; King, G.; Koike, I.; Smith, C. Biodiversity links above and below the marine sediment-water interface that may influence community stability. Biol. Conserv. 2002, 11, 113-136.

121. Macleod, C.K.; Moltschaniwskyj, N.A.; Crawford, C.M. Ecological and functional changes associated with long-term recovery from organic enrichment. Mar. Ecol. Prog. Ser. 2008, 365, 17-24.

122. Heilskov, A.C.; Alperin, M.; Holmer, M. Benthic fauna bio-irrigation effects on nutrient regeneration in fish farm sediments. J. Exp. Mar. Biol. Ecol. 2006, 339, $204-225$.

123. Hooper, D.U.; Chapin, F.S.; Ewel, J.J.; Hector, A.; Inchausti, P.; Lavorel, S.; Lawton, J.H.; Lodge, D.M.; Loreau, M.; Naeem, S.; Schmid, B.; Setala, H.; Symstad, A.J.; Vandermeer, J.; Wardle, D.A. Effects of biodiversity on ecosystem functioning: A consensus of current knowledge. Ecol. Monogr. 2005, 75, 3-35.

124. Bolam, S.G.; Fernandes, T.F.; Huxham, M. Diversity, biomass, and ecosystem processes in the marine benthos. Ecol. Monogr. 2002, 72, 599-615.

125. Tilman, D.; Knops, J.; Wedin, D.; Reich, P.; Ritchie, M.; Siemann, E. The influence of functional diversity and composition on ecosystem processes. Science 1997, 277, 1300-1302.

126. Wohl, D.L.; Arora, S.; Gladstone, J.R. Functional redundancy supports biodiversity and ecosystem function in a closed and constant environment. Ecology 2004, 85, 1534-1540.

127. Lohrer, A.M.; Thrush, S.F.; Gibbs, M.M. Bioturbators enhance ecosystem function through complex biogeochemical interactions. Nature 2004, 431, 1092-1095.

128. Paine, R.T. A Conversation on refining the concept of keystone species. Conserv. Biol. 1995, 9, 962-964.

129. Widdicombe, S.; Austen, M.C. Experimental evidence for the role of Brissopsis lyrifera (Forbes, 1841) as a critical species in the maintenance of benthic diversity and the modification of sediment chemistry. J. Exp. Mar. Biol. Ecol. 1998, 228, 241-255.

130. Emmerson, M.C.; Solan, M.; Emes, C.; Paterson, D.M.; Raffaelli, D. Consistent patterns and the idiosyncratic effects of biodiversity in marine ecosystems. Nature 2001, 411, 73-77. 
131. Covich, A.P.; Austen, M.C.; Barlocher, F.; Chauvet, E.; Cardinale, B.J.; Biles, C.L.; Inchausti, P.; Dangles, O.; Solan, M.; Gessner, M.O.; Statzner, B.; Moss, B. The role of biodiversity in the functioning of freshwater and marine benthic ecosystems. Bioscience 2004, 54, 767-775.

132. Snelgrove, P.; Blackburn, T.H.; Hutchings, P.A.; Alongi, D.M.; Grassle, J.F.; Hummel, H.; King, G.; Koike, I.; Lambshead, P.J.D.; Ramsing, N.B.; Solis-Weiss, V. The importance of marine sediment biodiversity in ecosystem precesses. Ambio. 1997, 26, 578-583.

133. Papageorgiou, N.; Sigala, K.; Karakassis, I. Changes of macrofaunal functional composition at sedimentary habitats in the vicinity of fish farms. Esturar. Coast. Shelf Sci. 2009, 83, 561-568.

134. Hooper, D.U.; Solan, M.; Symstad, A.; Diaz, M.; Gessner, M.O.; Buchmann, N.; Degrange, V.; Grime, P.; Hulot, F.; Mermillod-Blondin, F.; Roy, J.; Spehn, E.; van Peer, L. Species diversity, functional diversity and ecosystem functioning. In Biodiversity and Ecosystem Functioning; Loreau, M., Naeem, S., Inchausti, P., Eds.; Oxford University Press: Oxford, UK, 2002.

135. Pearson, T.H. Functional group ecology in soft-sediment marine benthos: The role of bioturbation. Oceanogr. Mar. Biol.: Annu. Rev. 2001, 39, 233-267.

136. Norling, K.; Rosenberg, R.; Hulth, S.; Gremare, A.; Bonsdorff, E. Importance of functional biodiversity and species-specific traits of benthic fauna for ecosystem functions in marine sediment. Mar. Ecol. Prog. Ser. 2007, 332, 11-23.

137. Petchey, O.L.; Gaston, K.J. Functional diversity (FD), species richness and community composition. Ecol. Lett. 2002, 5, 402-411.

(C) 2011 by the authors; licensee MDPI; Basel; Switzerland. This article is an open access article distributed under the terms and conditions of the Creative Commons Attribution license (http://creativecommons.org/licenses/by/3.0/). 